\title{
Deprivation and access to work in Dublin city: The Impact of Transport Disadvantage
}

Aoife Ahern $^{a}$, Amaya Vega $^{b}$, Brian Caulfield $^{c}$

${ }^{a}$ School of Civil Engineering, Richview Newstead, Belfield, Dublin 4, Ireland

${ }^{b}$ Whitaker Institute, J.E. Cairnes Building, National University of Ireland, Galway, Ireland

'Department of Civil, Structural and Environmental Engineering, Trinity College Dublin, Dublin 2, Ireland

\begin{abstract}
Ireland's economy underwent a period of rapid expansion between 1995 and 2007, accompanied by a boom in construction. The subsequent decade saw a rapid decline in construction as Ireland went through an unprecedented recession. This paper examines how this boom and bust has influenced deprivation and accessibility in Dublin. The paper examines, through a logit model, links between transport disadvantage, deprivation and employment accessibility in the city. The paper concludes that links exist between deprivation and accessibility in the city, in particular in the newer peripheral suburbs, leaving these areas open to risk of transport poverty.
\end{abstract}

\section{Introduction:}

Ireland underwent a period of rapid economic expansion between 1995 and 2007, followed by an unprecedented economic crash in 2008. As Ireland now emerges from that period of recession, the impacts on deprivation and social exclusion need to be assessed. In this paper, the relationship between transport disadvantage, deprivation and employment accessibility in Dublin are examined.

The paper describes patterns of transport disadvantage in Dublin City by examining the spatial distribution of accessibility to employment and deprivation in the city. An accessibility model is used to generate accessibility scores at the electoral district level. The research then uses the All-Ireland Deprivation Index (Haase and Pratschke, 2011) to compare levels of deprivation and access to employment across Dublin electoral districts. Following on from this, districts in 
Dublin are categorized by accessibility and deprivation levels and a multinomial logit model is estimated using data from the 2011 Census of Population of Ireland. The model estimates the relationship between the level of accessibility to employment and a number of socio-economic and land use variables including deprivation, car ownership, and public transport accessibility amongst others. The research presented in this paper adds to the growing body of work in the field of transport disadvantage by combining a number of methodologies, namely, accessibility and regression analysis with unique national datasets. Previous studies in this field have used surveys and case studies to examine the issue of transport disadvantage and its relationship with other socio-economic variables (Preston, 2009). This paper is one of the first to use national census data to determine these relationships over a large metropolitan area that has just emerged from an economic crisis. Research in this field has also tended to focus on particular social groups, whereas in this paper the focus is on all individuals living in Dublin.

The paper is structured as follows: Section 2 will briefly describe existing studies of transport disadvantage and social exclusion, including the definitions that are being used in this research for both of these terms and gives a context for the study. Section 3 outlines the accessibility model used in the study. Section 4 describes the multinomial logit model, while section 5 gives an overview of results and analysis. Section 6 outlines the conclusions of the paper.

\section{Transport Disadvantage and Social Exclusion}

Research into the relationships between accessibility, transport disadvantage and social exclusion is an important area (Jones and Lucas, 2012; Markovich and Lucas, 2011; Preston, 2009; Rock et al, 2016). However, some researchers (Markovich and Lucas, 2011; Rock et al 2016) would argue that the social impacts of transport and the impacts of accessibility on deprivation have been less widely studied than the impacts of transport on the environment or on the economy. A lot of the research in the area, as pointed out by both Rock et al (2016) and Delbosc and Currie (2011) has tended to focus on particular groups which are seen as socially disadvantaged (for example lone parents or older people) or on areas that have particular 
geographical characteristics that make transport more difficult (for example rural areas or urban peripheries).

Lucas (2012) points out that transport disadvantage and transport related social exclusion can be related but are not the same thing. Lucas states that it is possible to have good access to transport, but be socially excluded, and vice versa (Lucas, 2012). However, if one is both transport and socially disadvantaged this can, according to Lucas, lead to transport poverty and poor accessibility to services and jobs, and to social exclusion. In this paper, we look at areas in Dublin and categorise them according to accessibility and deprivation to assess if those areas which are both transport and socially disadvantaged experience the greatest difficulties in accessing employment.

In their seminal paper, Kenyon et al., (2002) introduce a mobility dimension to social exclusion and provide the definition as the process by which people are prevented from participating in the economic, political and social life of the community due to reduced accessibility to opportunities, including employment (Kenyon et al., 2002). Access to employment constitutes a key structural factor that influences the (re)production of mobility-related transport disadvantage (Rau and Vega, 2012). The concept of accessibility, that is, the availability of opportunities for face-to-face social interaction and economic activity, is of particular relevance in this context (Preston and Rajé 2007). Handy and Niemeier (1997) suggest that the concept of accessibility is determined by a number of elements: the spatial distribution of opportunities at the destination, their magnitude, quality and character, and the characteristics of the transport system in terms of the ease of reaching the destination. Accessibility is thus determined by the patterns of land use and the nature of the transportation system (Handy and Niemeier 1997). However, it is the individual dimension of accessibility, which reflects the needs, abilities and opportunities for a particular individual, what makes accessibility measures vary across individuals and social groups (Geurs and Van Wee 2004; Rau and Vega 2012).

Jones and Lucas (2012) state that there are 3 scales of accessibility: micro which is concerned with access to vehicles (for example of disabled people or those travelling with children), meso 
which is concerned with network connectivity and strategic which is concerned with access to employment at a sub-regional level. It is the latter that this paper is concerned with. However, as Jones and Lucas (2012) point out for people to enjoy good accessibility there must be good performance at all scales.

Currie and Delbosc (2013) describe the existence of transport disadvantage and poor accessibility in the suburbs of Australian cities, and state that in those suburbs evidence exists of "Forced Car Ownership". This is where poor access to alternatives modes and low levels of accessibility have led to those who cannot afford to own a car being forced to own a car in order to be able to access employment and activities. Car dependency is high as access to services can only be achieved through car ownership and car use. Currie et al (2009) argue that low income households need to be located near public transport and in activity centres (for example near jobs) to reduce the need to own a car and to reduce transport disadvantage. Currie et al (2011) also found that in fringe suburbs residents had poor access to social and leisure activities, to a greater extent than that to work activities.

The previous literature in this growing field is very rich and points to some of the global trends emerging in this field. This paper adds to this field in two ways, firstly it examines using census data the relationships between deprivation and accessibility. Secondly, the paper examines Dublin, a city that has just emerged from an economic crisis, and the case study area provides interesting insights into the relationships between transport and inequality.

\section{Accessibility model}

There is a wide range of methodologies and approaches to the measurement of accessibility (see comprehensive reviews in Handy and Niemeier, 1997; Geurs and Ritsema van Eck, 2003; Halden, 2002; Geurs and van Wee, 2004; Martin and Reggiani, 2011; Willigers et al., 2007).

Overall, the definition and mathematical formulation of accessibility depends on the objectives of the particular study for which the accessibility measure is intended for (Borzacchiello et al., 
2010). Several formulations of accessibility may lead to different results for the same transport network and land use context (Reggiani et al., 2007; Borzacchiello et al. 2010).

From the broad range of existing methodologies, a modified version of the traditional gravitybased model - also known as economic potential - is used in this paper for the computation of accessibility indicators. The gravity model is a well-established methodology in accessibility research. Based on a model of social behaviour that predicts that the interaction between residential and employment locations decline with increasing travel distance, time or cost, gravity-based measures of accessibility weight opportunities by travel impedance, which means that accessibility decreases as the travel time or distance to the opportunity increases. The accessibility scores obtained can be interpreted as the volume of economic activity to which an area has access to, after the cost/time of covering the distance to that activity has been accounted for (Dundon-Smith and Gibb, 1994). The mathematical function used to represent the spatial separation between origins and destinations, also known as the travel impedance function, plays a crucial role in computing accessibility measures. Some studies use exponential functions (Wilson, 1971) or Gaussian functions (Ingram, 1971). The negative exponential function is most closely associated with travel behaviour theory and has been widely used in international transport studies (Handy and Niemeier, 1997).

Some of the theoretical limitations of the gravity model for accessibility analysis relate to the exclusion of competition effects regarding access to employment (Geurs and van Wee, 2004). To overcome this limitation, a modified version of the gravity model is used in the paper. Shen (1998) suggests that the traditional gravity-based accessibility measure is only useful when either one of the following conditions is satisfied: (1) the demand for available opportunities is uniformly distributed across space and (2) the available opportunities have no limitation in capacity. As regards to employment opportunities, neither the first nor the second condition holds. Employment is characterised by its non-random spatial distribution and jobs are limited to one worker accessing them, which represents a clear limitation in capacity. 
Shen (1998) thus proposes a modified version of the traditional gravity-based accessibility measure to account for both the uneven spatial distribution of jobs and the effect of competition for jobs at each location. The advantage of Shen's (1998) proposal is that it considers not only the number of available employment opportunities at the destination, but also the number of job seekers by occupation type or demand potential. In this paper, the spatial unit of analysis is the electoral district.

Accessibility is computed following Shen's (1998) formulation below:

\section{Equation 1}

$$
\begin{aligned}
& A_{i}=\sum_{j} E_{j} f\left(c_{i j}\right) / D_{j} \\
& D_{j}=\sum_{k} \alpha_{k} P_{k} f\left(c_{k j}\right)
\end{aligned}
$$

where:

Ai is the accessibility index for people living in location i (origin);

Ej is the number of employment opportunities in destination $\mathrm{j}$;

$\mathrm{Pk}$ is the number of job seekers living in zone $\mathrm{k}$;

$\mathrm{Dj}$ is the demand potential. This is used to take into account the fact that the spatial distribution of the demand, which is not uniform;

$\alpha_{k}$ is the proportion of households at location $\mathrm{k}$ that have access to one or more cars;

$\mathrm{f}(\mathrm{ckj})$ is the impedance function measuring the spatial separation between $\mathrm{k}$ and $\mathrm{j}$. The functional form is equal to $\exp \left(-\beta T_{i j}\right)$ where exp is the base of the natural logarithms and $\beta$ is the impedance parameter. This parameter is empirically calibrated through simple 
regression analysis to maximize the fit between the predictions of the gravity model and the actual observed cost of travel, $\mathrm{Tij}[1]$. Travel times in minutes from zone $\mathrm{i}$ to zone $\mathrm{j}$ are used as the cost of travel.

For an urban or regional system with $\mathrm{N}$ locations, $\mathrm{i}=1,2, \ldots, \mathrm{N}, \mathrm{j}=1,2, \ldots, \mathrm{N}$ and $\mathrm{k}=1,2, \ldots, \mathrm{N}$.

The ESRI's ArcGIS Network Analyst extension was used to generate an origin-destination matrix based on travel times from each origin to each destination in the study area. This is then used for the computation of an index of accessibility to employment for Dublin City. Following Shen's (1998) formulation, the accessibility index took into account the supply and demand of job opportunities at each electoral district, the travel time from each residential location to each employment centre, car availability at the household level and the travel time experienced in the journey to work.

\section{Study Context}

The study area is the County Dublin Borough. The study area is shown in Figure 1. It consists of 4 regional authority areas: Fingal to the north of the county, Dun Laoghaire-Rathdown to the southeast, South County Dublin to the south and Dublin City Council, covering the city centre region.

\footnotetext{
${ }^{1}$ Due to the lack of reliable data on the impedance parameter for job accessibility, this parameter was estimated as the natural log
} 


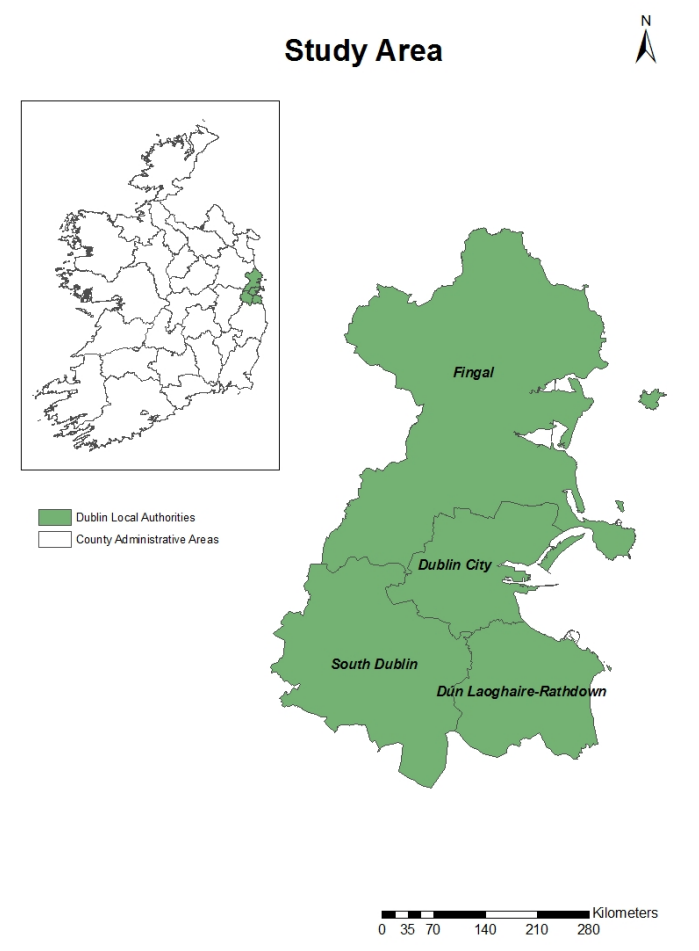

Figure 1 Study Area with Dublin's four local authorities: Fingal, South Dublin, Dun-Laoghaire-Rathdown and Dublin City

Table 1 shows the population of the region and each local authority and how this has grown between the last 2 census periods from 2006 to 2011 (Source CSO, 2011).

Table 1 Population changes in Dublin between 2006 and 2011 (Source: Central Statistics Office, www.cso.ie)

\begin{tabular}{|l|l|l|l|}
\hline Local Authority & $\begin{array}{l}\text { Population in } \\
\mathbf{2 0 0 6}\end{array}$ & $\begin{array}{l}\text { Population in } \\
\mathbf{2 0 1 1}\end{array}$ & $\begin{array}{l}\text { Change in } \\
\text { Population (\%) }\end{array}$ \\
\hline Dublin City & 506,211 & 527,612 & 3.8 \\
\hline Dun Laoghaire-Rathdown & 194,038 & 206,261 & 6.7 \\
\hline Fingal & 239,992 & 273,991 & 13.8 \\
\hline South Dublin & 246,935 & 265,205 & 7.4 \\
\hline Total: & $1,118,176$ & $1,273,069$ & 7.0 \\
\hline
\end{tabular}

As Table 1 demonstrates, population growth in the region has been significant, but it has not been evenly distributed: growth has been particularly high in Fingal, and the peripheral suburbs of this area. Population growth in the city centre has been much lower. Dublin is a city that has undergone considerable change in the past 15 years. The suburbs have grown and there has been increased decentralisation of housing and employment away from the city to the suburbs, 
in particular the northern suburbs of Fingal. Between 2001 and 2007, significant amounts of housing were built in Dublin. Since the economic downturn in 2008, however, construction in the city has stalled, as it has across Ireland. According to the CSO (2011), between 2001 and 2006, housing stock grew by 21.2\% in Ireland. Between 2006 and 2011, the growth in housing stock was only $12.7 \%$.

The accessibility values for Dublin ranged from 0.47 to 1.94 (with a standard deviation of 0.334). The accessibility was examined and split into quartiles. The quartiles use are categorised by level of access, these levels were estimated using equation 1. Quartiles were used as this enabled the estimation of a dependant variable for the subsequent Multinomial logistic (MNL) models. Figure 2 shows the mapping of these quartiles in Dublin. It is apparent that those areas with worst accessibility are on the periphery of the region. Those areas with good or best access are located closest to the city, with some areas of good access also in Dun Laoghaire-Rathdown and along the coast.

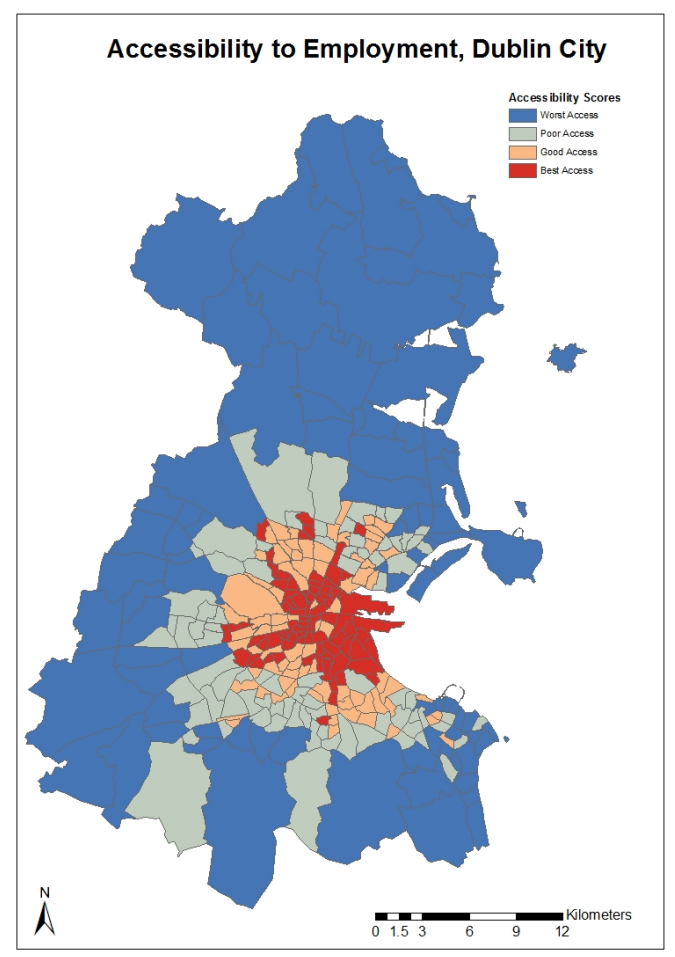

Figure 2 Accessibility in Dublin 
Table 2 presents the data that was used in this study. The data comes from the 2011 census of Ireland. This dataset is called Place of Work, School or College-Census of Anonymised Records or POWSCAR (CSO, 2011). The 2011 census was conducted on the night of the $10^{\text {th }}$ April 2011. The POWSCAR dataset contains data on almost 2.8 million people and if they were in education or employment how they travelled to their place of education or employment in Ireland.

Car ownership levels in Dublin are increasing and previous research has shown how individuals living in housing built during the housing boom (1995-2005) were more likely to have poorer access to public transport and more likely to own multiple cars (McGoldrick and Caulfield, 2015). Car ownership is an important variable and is examined in Table 2. The results show, as one might expect, that those living in the areas with the worst access were more likely to own a car, or multiple cars. Public transport access is also examined in Table 2 and it shows, again as one would expect, that those who are living in areas with poor access have less access to public transport. These results, while intuitive, provide some context to the subsequent sections. These findings suggest areas with poor access have lower levels of public transport availability and higher levels of car ownership. Having identified this, the next step is to determine if these areas with poor access are also the areas with higher levels of deprivation.

Table 2 Data used in the study

\begin{tabular}{|l|l|l|l|l|l|l|l|l|}
\hline & Worst Access & \multicolumn{2}{l|}{ Poor Access } & \multicolumn{2}{l|}{ Good Access } & \multicolumn{2}{l|}{ Best Access } \\
\hline & & & & & & & & \\
\hline SEG (Socio Economic Group) & & & & & & & & \\
\hline Employers and managers & 24977 & 19.4 & 24235 & 20.3 & 26489 & 18.9 & 21944 & 16.8 \\
\hline Higher professional & 10407 & 8.1 & 11724 & 9.8 & 16039 & 11.4 & 18234 & 14.0 \\
\hline Lower professional & 20359 & 15.8 & 19367 & 16.2 & 24429 & 17.4 & 22885 & 17.5 \\
\hline Non-manual & 36892 & 28.6 & 33408 & 28.0 & 38676 & 27.6 & 34967 & 26.8 \\
\hline Manual skilled & 9404 & 7.3 & 7580 & 6.3 & 8574 & 6.1 & 5738 & 4.4 \\
\hline Semi-skilled & 10501 & 8.1 & 8909 & 7.5 & 10331 & 7.4 & 9213 & 7.1 \\
\hline Unskilled & 3433 & 2.7 & 3289 & 2.8 & 4131 & 2.9 & 5336 & 4.1 \\
\hline All others & 13073 & 10.1 & 10902 & 9.1 & 11696 & 8.3 & 12170 & 9.3 \\
\hline Total & 129046 & 100.0 & 119414 & 100.0 & 140365 & 100.0 & 130487 & 100.0 \\
\hline Car ownership & & & & & & & & \\
\hline No car & 5421 & 4.4 & 7483 & 6.5 & 13190 & 9.8 & 35374 & 29.2 \\
\hline One Car & 42760 & 34.5 & 40957 & 35.7 & 50815 & 37.8 & 50364 & 41.5 \\
\hline Two cars & 60542 & 48.8 & 50618 & 44.2 & 53134 & 39.5 & 28131 & 23.2 \\
\hline
\end{tabular}




\begin{tabular}{|l|l|l|l|l|l|l|l|l|}
\hline Three or more cars & 15283 & 12.3 & 15561 & 13.6 & 17252 & 12.8 & 7432 & 6.1 \\
\hline Total & 124006 & 100.0 & 114619 & 100.0 & 134391 & 100.0 & 121301 & 100.0 \\
\hline Rail stop available & & & & & & & & \\
\hline Yes & 61449 & 47.6 & 34321 & 28.7 & 29503 & 21.0 & 39663 & 30.4 \\
\hline No & 67597 & 52.4 & 85093 & 71.3 & 110862 & 79.0 & 90824 & 69.6 \\
\hline Total & 129046 & 100.0 & 119414 & 100.0 & 140365 & 100.0 & 130487 & 100.0 \\
\hline Bus stops per 1,000 & & & & & & & & \\
\hline 10 or less bus stops & 84134 & 67.1 & 47993 & 43.6 & 54935 & 40.1 & 56178 & 46.8 \\
\hline 11 or more bus stops & 41212 & 32.9 & 62106 & 56.4 & 81913 & 59.9 & 63759 & 53.2 \\
\hline Total & 125346 & 100.0 & 110099 & 100.0 & 136848 & 100.0 & 119937 & 100.0 \\
\hline Year Built & & & & & & & & \\
\hline Before 1960 & 12732 & 9.9 & 18318 & 15.3 & 46885 & 33.4 & 67486 & 51.7 \\
\hline 1961-1980 & 22561 & 17.5 & 36491 & 30.6 & 38235 & 27.2 & 12673 & 9.7 \\
\hline 1981-2000 & 46605 & 36.1 & 32506 & 27.2 & 27332 & 19.5 & 22848 & 17.5 \\
\hline After 2001 & 47148 & 36.5 & 32099 & 26.9 & 27913 & 19.9 & 27480 & 21.1 \\
\hline Total & 129046 & 100.0 & 119414 & 100.0 & 140365 & 100.0 & 130487 & 100.0 \\
\hline Home ownership & & & & & & & & \\
\hline Owned & 94649 & 75.9 & 81432 & 70.6 & 94307 & 69.8 & 53832 & 44.0 \\
\hline Rented & 30050 & 24.1 & 33853 & 29.4 & 40753 & 30.2 & 68556 & 56.0 \\
\hline Total & 124699 & 100.0 & 115285 & 100.0 & 135060 & 100.0 & 122388 & 100.0 \\
\hline Deprivation variable & & & & & & & & \\
\hline Deprived area & 88732 & 68.9 & 63444 & 53.1 & 79549 & 58.8 & 64301 & 50.2 \\
\hline Affluent area & 40060 & 31.1 & 55970 & 46.9 & 55638 & 41.2 & 63766 & 49.8 \\
\hline Total & 128792 & 100.0 & 119414 & 100.0 & 135187 & 100.0 & 128067 & 100.0 \\
\hline
\end{tabular}

The first set of variables relates to deprivation. This measure of deprivation uses a number of demographic, social class and labour market factors to estimate the relative deprivation of an area (Haase and Pratschke, 2012). In this paper the deprivation takes a binary format, with those in deprived areas being all those individuals living in an area with a deprivation score of zero or less and those in an affluent areas had a deprivation score of above zero. This data takes a number of values into account to estimate deprivation such as; education levels, unemployment, professional classes and the lone parent rates to estimate this index (Haase and Pratschke, 2012). Figure 3 shows the deprivation index for Dublin. Deprivation is highest in the northern (Fingal) and south-western (South Dublin) suburbs. Dun Laoghaire-Rathdown, to the southeast, is a relatively affluent part of Dublin. The household compositions across the 4 areas is also different. In Dublin as a whole, the average number of people per household is 2.7 but this ranges from 2.4 per household in Dublin City to 2.9 per household in Fingal and South Dublin. In Dun Laoghaire-Rathdown, this stands at 2.7 per household (CSO, 2011). Unemployment, at the time of the 2011 census, was $17.1 \%$ across Dublin as a whole: this ranged from $11.2 \%$ in Dun Laoghaire-Rathdown to $19.6 \%$ in South Dublin (16\% in Fingal and $18.5 \%$ in Dublin City). Car is the main mode to work across Dublin with $49.3 \%$ of commuting 
trips being made by car drivers: across the 4 regional authorities this figure stands at $36 \%$ in Dublin City, 54.2\% in Dun Laoghaire-Rathdown, 58.9\% in Fingal and 62.3\% in South Dublin.

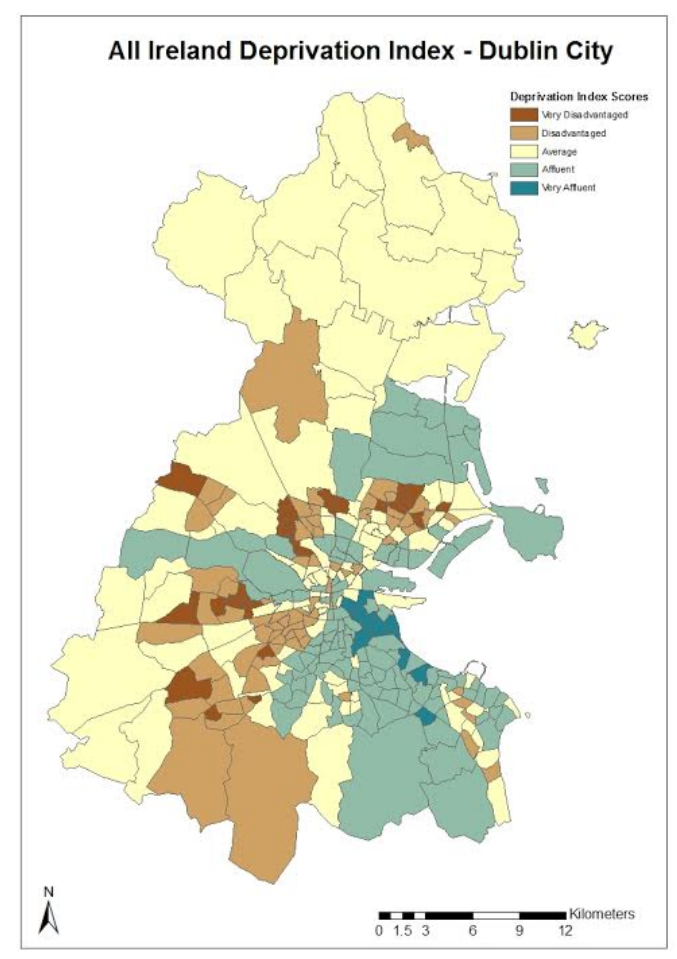

Figure 3 Deprivation index for Dublin (amended Haase and Pratschke (2011))

\section{Multinomial Logit Model}

The accessibility quartile as defined above was used as the dependent variable in the model. The independent variables, presented in Table 3, range from variables that look specifically at household structure to variables that look at access to public transport and deprivation. The multinomial logit model takes the following functional form:

\section{Equation 2}

$\operatorname{logit}(p)=\log \frac{p}{1-p}=a+\beta I+e$ 
where $p$ is the probability that event $Y$ occurs (in the case of this study it is the probability that someone lives in an area with different levels of accessibility). $8 /$ is the set of individual specific dependent variables. $\alpha$ is a parameter estimated by the model and $e$ is an error term.

Table 3 MNL variables

\begin{tabular}{|c|c|}
\hline \multicolumn{2}{|l|}{\begin{tabular}{|l} 
Variable \\
Accessibility
\end{tabular}} \\
\hline Accessibility & \\
\hline Worst Access & $=1$ if Accessibility: $<1$ \\
\hline Poor Access & $=1$ if Accessibility: $1-1.25$ \\
\hline Good Access & $=1$ if Accessibility: $1.25-1.50$ \\
\hline Best Access & Reference category $=$ Accessibility: $>1.5$ \\
\hline \multicolumn{2}{|l|}{ Socio-Economic group (SEG) } \\
\hline Higher professional & $=1$ if SEG: Higher professional \\
\hline Lower professional & $=1$ of SEG: Lower professional \\
\hline Non-manual & $=1$ of SEG: Non-manual \\
\hline Manual skilled & $=1$ of SEG: Manual skilled \\
\hline Semi-skilled & $=1$ of SEG: Semi-skilled \\
\hline Unskilled & $=1$ of SEG: Unskilled \\
\hline Own account workers & $=1$ of SEG: Own account workers \\
\hline Farmers & $=1$ of SEG: Farmers \\
\hline Agricultural workers & $=1$ of SEG: Agricultural workers \\
\hline All others & Reference category = SEG: All others \\
\hline \multicolumn{2}{|l|}{ Household Composition (HC) } \\
\hline Single Person & $=1$ if $\mathrm{HC}$ : Single Person \\
\hline $\begin{array}{l}\text { Lone parent with at least one resident child } \\
\text { aged } 19 \text { or under }\end{array}$ & $\begin{array}{l}=1 \text { if } \mathrm{HC} \text { : Lone parent with at least one } \\
\text { resident child aged } 19 \text { or under }\end{array}$ \\
\hline $\begin{array}{l}\text { Lone parent with resident children but none } \\
\text { aged } 19 \text { or under }\end{array}$ & $\begin{array}{l}=1 \text { if } \mathrm{HC} \text { : Lone parent with resident children } \\
\text { but none aged } 19 \text { or under }\end{array}$ \\
\hline $\begin{array}{l}\text { Couple with at least one resident child aged } \\
19 \text { or under }\end{array}$ & $\begin{array}{l}=1 \text { if } \mathrm{HC} \text { : Couple with at least one resident } \\
\text { child aged } 19 \text { or under }\end{array}$ \\
\hline $\begin{array}{l}\text { Couple with resident children but none aged } \\
19 \text { or under }\end{array}$ & $\begin{array}{l}=1 \text { if } \mathrm{HC}: \text { Couple with resident children but } \\
\text { none aged } 19 \text { or under }\end{array}$ \\
\hline Couple with no resident children & $=1$ if $\mathrm{HC}$ : Couple with no resident children \\
\hline Others & Reference category = HC: Others \\
\hline \multicolumn{2}{|l|}{ Car ownership (CO) } \\
\hline No car & $=1$ if $\mathrm{CO}:$ No car \\
\hline One Car & $=1$ if CO: One Car \\
\hline Two cars & $=1$ if $\mathrm{CO}:$ Two cars \\
\hline Three or more cars & $\begin{array}{l}\text { Reference category = OC: Three or more } \\
\text { cars }\end{array}$ \\
\hline \multicolumn{2}{|l|}{ Rail stop available } \\
\hline Yes & $=1$ if Rail availability: Yes \\
\hline No & Reference category = Rail availability: No \\
\hline \multicolumn{2}{|l|}{ Bus stops per 1,000} \\
\hline $0-2$ bus stops & $=1$ if Bus stops per $1,000: 0-2$ bus stops \\
\hline $3-5$ bus stops & $=1$ if Bus stops per $1,000: 3-5$ bus stops \\
\hline
\end{tabular}




\begin{tabular}{|c|c|}
\hline $6-10$ bus stops & $=1$ if Bus stops per $1,000: 6-10$ bus stops \\
\hline $11-15$ bus stops & $=1$ if Bus stops per $1,00: 011-15$ bus stops \\
\hline $16+$ bus stops & $\begin{array}{l}\text { Reference category = Bus stops per } 1,000 \text { : } \\
16+\text { bus stops }\end{array}$ \\
\hline \multicolumn{2}{|l|}{ Year Built } \\
\hline Before 1960 & $=1$ if Year Built: Before 1960 \\
\hline $1961-1980$ & $=1$ if Year Built: 1961-1980 \\
\hline $1981-2000$ & $=1$ if Year Built: $1981-2000$ \\
\hline After 2001 & Reference category = Year Built: After 2001 \\
\hline \multicolumn{2}{|c|}{ Deprivation score } \\
\hline Deprived Area & $=1$ if Deprivation score: -28 to 0 \\
\hline Affluent Area & $\begin{array}{l}\text { Reference category }=\text { Deprivation score } \\
\text { Greater than } 0\end{array}$ \\
\hline
\end{tabular}

\section{Results}

The results presented in Table 4 present the MNL models run using accessibility as the dependent variable and a series of independent variables, describing the socio-economic characteristics of the population under study and the land use characteristics of the Dublin electoral districts. The model uses the areas with the best access as the reference variable. The model has a very good Nagelkerke R2 of 0.415 , demonstrating the model has a good fit. The first sets of results show that for socio-economic group (SEG) that those living in the worst and poor access areas were more likely to be in the lower SEGs such as manual, semi-skilled and unskilled workers, although the trend is not very strong. Whereas the opposite is true for those living in areas with good access: that is those living in areas of good access are in the higher SEGs. 
Table 4 MNL Results

\begin{tabular}{|c|c|c|c|c|c|c|}
\hline & Coefficient & $\begin{array}{l}\text { Std. } \\
\text { Error }\end{array}$ & Coefficient & $\begin{array}{l}\text { Std. } \\
\text { Error }\end{array}$ & Coefficient & $\begin{array}{l}\text { Std. } \\
\text { Error }\end{array}$ \\
\hline \multirow[t]{2}{*}{ Intercept } & .322 & .028 & 1.356 & .027 & .990 & .026 \\
\hline & \multicolumn{2}{|c|}{ Worst access } & \multicolumn{2}{|c|}{ Poor access } & \multicolumn{2}{|c|}{ Good access } \\
\hline \multicolumn{7}{|l|}{ SEG } \\
\hline $\begin{array}{ll}\text { Employers } & \text { and } \\
\text { managers } & \end{array}$ & -.429 & .022 & -.256 & .021 & .067 & .020 \\
\hline Higher professional & -1.016 & .024 & -.736 & .023 & .293 & .021 \\
\hline Lower professional & -.484 & .022 & -.337 & .022 & .042 & .020 \\
\hline Non-manual & -.183 & .021 & -.102 & .020 & .022 & .019 \\
\hline Manual skilled & .044 & .028 & .051 & .028 & .124 & .026 \\
\hline Semi-skilled & .142 & .026 & .131 & .025 & .145 & .024 \\
\hline Unskilled & .126 & .034 & -.081 & .033 & -.060 & .030 \\
\hline All others & $0^{\mathrm{b}}$ & & $0^{\mathrm{b}}$ & & $0^{\mathrm{b}}$ & \\
\hline \multicolumn{7}{|l|}{ Car ownership } \\
\hline No car & -2.550 & .025 & -2.004 & .023 & \begin{tabular}{|l|}
-1.422 \\
\end{tabular} & .020 \\
\hline One Car & 1.007 & .019 & .863 & .018 & .674 & .017 \\
\hline Two cars & .180 & .019 & .195 & .018 & .200 & .018 \\
\hline Three or more cars & $0^{\mathrm{b}}$ & & $0^{\mathrm{b}}$ & & $0^{\mathrm{D}}$ & 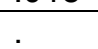 \\
\hline \multicolumn{7}{|l|}{ Rail stop available } \\
\hline Yes & 1.228 & .012 & .743 & .012 & 1.190 & .011 \\
\hline No & $0^{b}$ & & $0^{\mathrm{b}}$ & & $0^{\mathrm{D}}$ & 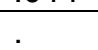 \\
\hline \multicolumn{7}{|l|}{ Bus stops per 1,000} \\
\hline 10 or less bus stops & 1.025 & .011 & -.169 & .010 & -.243 & .010 \\
\hline 11 or more bus stops & $0^{b}$ & 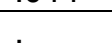 & $0^{\mathrm{b}}$ & & $0^{\mathrm{b}}$ & 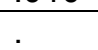 \\
\hline \multicolumn{7}{|l|}{ Year Built } \\
\hline Before 1960 & -2.918 & .015 & -2.040 & .014 & -.946 & .013 \\
\hline $1961-1980$ & -.953 & .016 & .221 & .016 & .380 & .016 \\
\hline $1981-2000$ & -.420 & .014 & -.144 & .014 & -.205 & .014 \\
\hline After 2001 & $0^{b}$ & & $0^{\mathrm{b}}$ & & $0^{b}$ & \\
\hline \multicolumn{7}{|l|}{ Home ownership } \\
\hline Owned & 1.180 & .012 & .802 & .011 & .688 & .010 \\
\hline Rented & $0^{\mathrm{b}}$ & & $0^{\mathrm{b}}$ & & $0^{\mathrm{b}}$ & \\
\hline \multicolumn{7}{|l|}{ Deprivation variable } \\
\hline Deprived area & .521 & .011 & -.326 & .010 & -.216 & .010 \\
\hline Affluent area & $0^{b}$ & 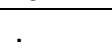 & $0^{b}$ & & $0^{b}$ & \\
\hline & \multirow{2}{*}{\multicolumn{6}{|c|}{437,112}} \\
\hline $\mathrm{N}$ & & & & & & \\
\hline Nagelkerke R2 & \multicolumn{6}{|l|}{.369} \\
\hline Chi-squared statistic & \multicolumn{6}{|l|}{19599.372} \\
\hline Degrees of freedom & \multicolumn{6}{|l|}{51} \\
\hline-2 log likelihood & \multicolumn{6}{|l|}{11793.407} \\
\hline
\end{tabular}

The results for household composition are mixed across each of the accessibility variables. One interesting variable to note is that single people were more likely to live in areas with good accessibility. As Figure 3 demonstrates, those areas with the best and good accessibility are more likely to be close to the city centre, where houses are smaller and there are more 
apartments. According to the $\mathrm{CSO}^{2}, 31.5 \%$ of housing in Dublin City regional authority is an apartment or flat, compared to $23 \%$ for the region as a whole. It may be that housing for families is not available in these areas of good or best accessibility.

In the most part, the results for car ownership are as one would expect. They show that those living in areas with poor accessibility were less likely not to own a car and the opposite was true for those in areas with good accessibility.

The findings for public transport availability show, as one would expect, that those in areas with better accessibility were more likely to have 11 or more bus stops per 1,000 of population. The figures for rail availability are harder to understand: however, this may be due to the limited amount of rail available in Dublin.

The year housing built variable shows that those living in areas of poor accessibility were more likely to be living in newer housing stock. These results mirror what was found in Caulfield \& Ahern, (2014). It emphasises that much of the newer housing built during the period of economic growth form 2001-2007 was not built in areas with good infrastructure, near the city; but instead these new housing areas were built in the outskirts where infrastructure had not been developed. When the economic downturn took place after 2007, investment in promised infrastructure for these post-2001 areas was postponed or cancelled.

The final set of variables examined in Table 4 are for deprivation: this is the variable of most interest in this study. The hypothesis as the start of this research was that those in the most deprived areas are also those most likely to be in areas of worst accessibility. The deprivation variable confirms that individuals living in the areas with the worst accessibility were most likely to also live in areas that are deprived. This issue raises several questions in relation to the social equity of transport accessibility in Dublin. It would appear that these areas have poor transport services, but in addition these are areas where people are most likely to suffer from

\footnotetext{
${ }^{2}$ http://www.cso.ie/en/media/csoie/releasespublications/documents/statisticalyearbook/2013/c20housing.pdf
} 
deprivation: they have worst access to jobs and least means available to them to be able to change this situation. This raises important questions about the links between transport disadvantage and social exclusion. As already remarked upon, Lucas (2012) points out that transport disadvantage and social exclusion are different things. However, in situations where both transport disadvantage and social exclusion exist, there is a risk of transport poverty. It would appear in Dublin that situation is in existence, where those who are most transport disadvantaged are also most likely to be living in areas of deprivation, with poor access to services and jobs, and, therefore, limited resources to reduce their levels of deprivation. This point is best illustrated by examining Figures 2 and 3. Figures 2 and 3 show that these areas of worst accessibility and deprivation are located in particular parts of the city: disadvantaged and very disadvantaged areas are for the most part in West and South-West Dublin, with smaller area of deprivation in the northern suburbs, on the border between Dublin City and Fingal.

The relationship between deprivation and accessibility is not, however, a simple one: the model shows that those living in areas of poor and good accessibility are less likely to be living in a deprived area than those with the best accessibility. This may be because some of those areas that are defined as having best accessibility are generally closer to the city centre (Figure 3) where both work and homes are close to each other and walking and cycling are easy. These city centre areas may be poor, with relatively high levels of unemployment, but access to transport is not a problem: walking, cycling and public transport are readily available and easy to use; while the jobs-housing balance is good. Looking in more detail at Figures 2 and 3, Figure 2 shows that in Dublin City there are areas that are disadvantaged and very disadvantaged scattered through the city, many in the south-west of Dublin City; but that in Figure 3 these are areas with are red or pink: indicating high levels of accessibility.

\section{Conclusion}

The paper set out to look at links between deprivation and transport disadvantage in Dublin at a period when Dublin has undergone rapid economic expansion followed by a significant 
downturn and recession. In the period of expansion, housing construction in Ireland was very high. Much of this housing, built between 2001 and 2007, was in the suburbs of Dublin, in the south-west and northern suburbs. These suburbs are the areas which it could be postulated have experienced some of the biggest challenges during the recession: all the houses in post 2001 areas were built and bought when prices were high and therefore have the greatest likelihood that people living in them are now in negative equity. These "new" areas also have less public transport infrastructure in place and higher reliance on the car (see Rock et al, 2016) than older areas. Therefore, as can be seen in this paper, when there newer, peripheral suburbs and estates suffer from deprivation this is also associated with transport disadvantage, leaving these locations more vulnerable to transport poverty, as put forward by Lucas (2012). Areas closest to the city centre are sometimes deprived (See Figure 2 and 3) but areas close to the city have much better accessibility, leaving these populations less vulnerable to transport poverty.

The findings are of importance to today as Dublin (and Ireland) emerge from recession into a period of growth. There are immense pressures on housing in Dublin as construction levels were so low between 2007 and 2014. However, in 2015, while housing construction is growing housing construction in Dublin has still not recovered: according to the Department of the Environment, only 2057 housing units were built in the first 9 months of 2015; compared to 17725 units in the whole of 2007 (Department of the Environment, 2015). The demand for housing is high, with the government Housing Agency (2014) stating that Dublin needs 7,500 new housing units per year for each of the 5 years between 2014 and 2018. This need is not currently being met. It is important that new housing construction is in locations with transport infrastructure already in place in order to avoid the mistakes made between 2001 and 2007. However, it would appear that housing is not being built in Dublin, but instead is being built in the commuter counties of Kildare, Wicklow and Meath - areas not looked at in this paper but which are peripheral to Dublin. If this continues to be the case, these areas are more vulnerable to transport disadvantage and transport poverty in any future downturns. 


\section{References:}

1. Borzacchiello, B., Nijkamp, P., Koomen, E., Accessibility and urban development: a gridbased comparative statistical analysis of Dutch cities. Environment and Planning B: Planning and Design, volume 37, 2010, pp 148-169.

2. Caulfield, B., Ahern, A., The Green Fields of Ireland: The Legacy of Dublin's Housing Boom and the Impact on Commuting, Case Studies on Transport Policy, Volume 2, Issue 1, July 2014, pp 20-27

3. Central Statistics Office. Census of Ireland, 2011, Dublin

4. Currie, G., Richardson, T. , Smyth, P., Vella-Brodrick, D., Hine, J., Lucas, K., Stanley, J., Morris, J., Kinnear, R. and Stanley, J., Investigating links between transport disadvantage, social exclusion and well-being in Melbourne - Preliminary Results, Transport Policy, Volume 16, 2009, pp 97-105.

5. Currie, G and Delbosc, A., Exploring Trands in Forced Car Ownership, Australian Transport Research Forum, 2013 Proceedings, October, 2013.

6. Delbosc, A. and Currie, G. The spatial context of transport disadvantage, social exclusion and well-being, Journal of Transport Geography, volume 19, 2011, pp 1130-1137.

7. Department of the Environment, http://www.environ.ie/en/Publications/StatisticsandRegularPublications/HousingStatist ics/, 2015.

8. Dundon Smith, D., Gibb, R., The Channel Tunnel and regional economic development, Journal of Transport Geography, Volume 2, Issue 3, 1994, pp 178-189.

9. Geurs, K. and Van Wee, B. Accessibility evaluation of land use and transport strategies: review and research directions, Journal of Transport Geography, volume 12, 2004, pp 127-140.

10. Geurs, K.T., J.R. Ritsema van Eck (2003) Accessibility evaluation of land-use scenarios: the impact of job competition, land-use and infrastructure developments for the Netherlands. Environment and Planning B: Planning \& design, 30, issue 1, 69 - 87.

11. Grengs, Joe. "Job accessibility and the modal mismatch in Detroit." Journal of Transport Geography 18.1 (2010): 42-54.

12. Haase, T., Pratschke, J. The 2011 Pobal HP Deprivation Index for Small Areas. 2012. Dublin.

13. Housing

Agency, http://www.environ.ie/en/Publications/StatisticsandRegularPublications/HousingStatist ics/, 2014.

14. Halden, D. Using accessibility measures to integrate land use and transport policy in Edinburgh and the Lothians, Transport Policy, volume 9, issue 4, 2002, pp 313-324.

15. Handy, S. and Neimier, D. Measuring Accessibility: An Exploration of Issues and Alternatives, Environment and Planning A, volume 29, issue 7, July 1997, pp 1175-1194.

16. Ingram, D., The concept of accessibility: A search for an operational form. Regional Studies volume 5, issue 2, 1971, pp101-107. 
17. Jones, P. and Lucas, K., The social consequences of transport decision-making: clarifying concepts, synthesising knowledge and assessing implications. Journal of Transport Geography, Volume 21, 2012, pp4-16.

18. Kenyon, S., Lyons G. and Rafferty, J., Transport and Social Exclusion: investigating the possibility of promoting inclusion through virtual mobility, Journal of Transport Geogrpahy, 10, pp 207-219.

19. Levinson, D. 1998. Accessibility and the journey to work. Journal of Transport Geography 6:11-21.

20. Lucas, K., Social Exclusion: Where are we now? Transport Policy, Volume 20, 2012, pp 105-113.

21. Martin, J., Reggiani, A., Recent Methodological Developments to Measure Spatial Interaction: Synthetic Accessibility Indices Applied to High-Speed Train Investments, Transport Reviews, Volume 27, Issue 5, 2007, pp 551-571.

22. Markovich, J., Lucas, K. The social and distributional effects of transport: a literature review, Working paper no 1, 2011, Transport Studies Unit, Oxford University,

23. McGoldrick, P., Caulfield, B, Examining the changes in car ownership levels in the Greater Dublin Area between 2006 and 2011, Case Studies on Transport Policy, 2015, p229- 237

24. Preston, J. Transport Policy and social exclusion -some reflections, Transport Policy, Volume 16, 2009, pp 140-142.

25. Preston, J. and Rajé F. , Accessibility, mobility and transport-related social exclusion, Journal of Transport Geography, Volume 15, 2007, 151-160.

26. Rau, H. and Vega, A., Spatial (Im)mobility and Accessibility in Ireland: Implications for Transport Policy, Growth and Change, Volume 4, Issue 4, October 2012, pp 667-696.

27. Reggiani, A., Bucci, P., Russo, G., Accessibility and Impedance Forms: Empirical Applications to the German Commuting Network, International Regional Science Review, Volume 34, April 2011, pp 230-252.

28. Rock, S., Ahern, A., Caulfield, B. The economic boom, bust and transport inequity in suburban Dublin, Ireland, Research in Transport Economics, 57, 2016, p13 - 20

29. Shen, Q.. Location characteristics of inner-city neighborhoods and employment accessibility of low-wage workers. Environment and Planning B volume 25, issue 3, 1998 , pp345-365.

30. Willigers, J., Floor, H., Van Wee, B., Accessibility Indicators for Location Choices of Offices: an application to the intraregional distributive effects of high-speed rail in the Netherlands. Environment and Planning A, volume 39, 2007, pp 2086-2098,

31. Wilson, A., A family of spatial interaction models, and associated developments. Environment and Planning, volume 3, issue 1, 1971, pp 1-32. 